\title{
Correction to: Using qualitative research to explore intervention mechanisms: findings from the trial of the learning together whole-school health intervention
}

Emily Warren $^{1 *}$, G. J. Melendez-Torres ${ }^{2}$, Russell Viner ${ }^{3}$ and Chris Bonell ${ }^{1}$

Correction to: Trials (2020) 21:774

https://doi.org/10.1186/s13063-020-04688-2

Following publication of the original article [1], we were notified of a mistake in the spelling of the second author.

- Incorrect spelling: Meledez-Torres

- Correct spelling: Melendez-Torres

The original article has been corrected.

\section{Author details}

${ }^{1}$ Faculty of Public Health and Policy, London School of Hygiene \& Tropical

Medicine, London, UK. ${ }^{2}$ University of Exeter, Exeter, UK. ${ }^{3}$ UCL Institute of

Child Health, London WC1N 1EH, UK.

Published online: 23 September 2020

\section{Reference}

1. Warren $\mathrm{E}$, et al. Using qualitative research to explore intervention

mechanisms: findings from the trial of the Learning Together whole-school health intervention. Trials. 2020;21:774. https://doi.org/10.1186/s13063-02004688-2.

The original article can be found online at https://doi.org/10.1186/s13063020-04688-2

* Correspondence: emily.warren@lshtm.ac.uk

${ }^{1}$ Faculty of Public Health and Policy, London School of Hygiene \& Tropical Medicine, London, UK

Full list of author information is available at the end of the article

(c) The Author(s). 2020 Open Access This article is licensed under a Creative Commons Attribution 4.0 International License, which permits use, sharing, adaptation, distribution and reproduction in any medium or format, as long as you give appropriate credit to the original author(s) and the source, provide a link to the Creative Commons licence, and indicate if changes were made. The images or other third party material in this article are included in the article's Creative Commons licence, unless indicated otherwise in a credit line to the material. If material is not included in the article's Creative Commons licence and your intended use is not permitted by statutory regulation or exceeds the permitted use, you will need to obtain permission directly from the copyright holder. To view a copy of this licence, visit http://creativecommons.org/licenses/by/4.0/. The Creative Commons Public Domain Dedication waiver (http://creativecommons.org/publicdomain/zero/1.0/) applies to the data made available in this article, unless otherwise stated in a credit line to the data. 